\title{
PENGARUH PROSES PENGADUKAN TANAH LIAT TERHADAP KUAT TEKAN BATA MERAH
}

\author{
Yovanda Putra Medika ${ }^{1)}$, Elhusna ${ }^{2)}$, Ade Sri Wahyuni ${ }^{3)}$ \\ ${ }^{122) 3)}$ Program Studi Teknik Sipil, Fakultas Teknik UNIB, Jl. W. R. Supratman, \\ Kandang Limun, Bengkulu 38371, Telp. (0736)344087 \\ email: yovandamedika@gmail.com
}

\begin{abstract}
Abstrak
Salah satu proses pembuatan bata merah konvesional yaitu proses pengadukan tanah liat, dimana pada proses pengadonan bata merah dilakukan dengan penginjakan. Penelitian ini bertujuan untuk mengetahui pengaruh dari lamanya waktu proses penginjakan adukan tanah liat terhadap sifat fisis bata merah. Metode yang digunakan dalam penelitian ini adalah metode eksperimen. Proses pembuatan bata dilakukan dengan cara yang dilakukan pabrik. Variasi durasi penginjakan adonan tanah liat adalah selama 20, 25, 30, 32, 35 dan 40 menit dimana 32 menit adalah waktu injak pabrik. Benda uji yang dibuat pada penelitian ini sebanyak 15 benda uji untuk bata normal dan 90 benda uji untuk bata variasi. Pengujian kuat tekan bata mengacu pada SNI 03-416-1996 dan menggunakan alat compression machine hand operated dengan kapasitas $250 \mathrm{kN}$. Kuat tekan bata merah terbesar terdapat pada bata dengan lama proses penginjakan adonan adukan selama 40 menit dengan kuat tekan 1,09 $\mathrm{MPa}$. Penelitian memperlihatkan bahwa persentase variasi pembuatan adukan yang lama penginjakannya meningkatkan kekuatan bata.
\end{abstract}

Kata kunci: bata merah, kuat tekan, proses pembuatan bata, waktu pengadukan

\begin{abstract}
One of the conventional brick production processes is the clay stirring process, which the red brick clay mortar mix is, done by stepping on it. This research is aimed to know the duration of stepping on the process of the clay mortar mixing to the red brick properties. The method of this research is experimental. The brick making process is done in the way that the factory does. The variation of stepping on brick dough is about 20, 25, 30, 32, 35 and 40 minutes where 32 minutes is factory time. The objects of the test created on this research is 15 for normal bricks and 90 for variation bricks. The testing of the compressive strength of the brick refers to SNI 03-416-1996 and uses the Compression Machine Hand Operated with capacity $250 \mathrm{kN}$. The biggest of of the compressive strength of the brick is on stepping on brick dough in 40 minutes with 1,09 MPa. This research shows that the length of the stirring process determines the strength of the produced bricks; simply put, the longer the stirring process gets, the stronger bricks become.
\end{abstract}

Keywords: red brick, compressive strenght, brick making proces, stirring time 


\section{PENDAHULUAN}

Batu bata adalah bahan bangunan yang diperuntukkan untuk kontruksi, dibuat dari tanah liat atau tanpa campuran bahan lain, dibakar dengan suhu yang tinggi, sehingga tidak mudah hancur bila direndam (SII0021-78 dalam Handayani, 2010). Penggunaan batu bata banyak digunakan untuk aplikasi teknik sipil seperti dinding pada bangunan perumahan, bangunan gedung, pagar, saluran dan pondasi.

Terdapat banyak jenis batu bata di Indonesia, diantaranya bata merah, batako, bataton, serta bata ringan. Jenis batu bata yang banyak digunakan di Indonesia merupakan bata merah lokal yang berbahan dasar tanah liat dan dicetak secara manual. Selain proses pembuatannya yang lebih mudah, bahan baku pembuatan bata merah ini pun banyak dijumpai di Indonesia (Rahman dkk, 2016).

Pembuatan batu bata memiliki langkahlangkah secara garis besar yaitu, pertama proses pembuatan adonan tanah untuk bata merah, kedua proses pencetakan bata dari bahan adonan yang telah dibuat, ketiga proses penyusunan bata untuk dikeringkan, kempat yaitu proses terakhir pembakaran untuk membuat bata merah yang berkualitas.

Salah satu proses pembuatan bata merah yaitu proses pembuatan adonan, dimana pada proses ini memerlukan waktu untuk proses pengadonan bata merah. Tujuan penelitian ini melihat pengaruh lama waktu penginjakan adonan terhadap kuat tekan bata merah.

Bata merah merupakan salah satu bahan bangunan berbentuk prismatik dengan ukuran tertentu yang terbuat dari tanah liat dengan atau tanpa tambahan bahan lain yang sering digunakan sebagai pasangan dinding, dibuat melalui proses pembentukan, pengeringan dan pembakaran sehingga menjadi keras, tidak mudah hancur dalam air serta tahan api (Raharjo dkk, 2015).

Material pembentuk bata merah antara lain yaitu tanah dan air.Tanah adalah hasil pengalihragaman bahan mineral dan organik yang berlangsung di muka daratan bumi di bawah pengaruh faktor-faktor lingkungan yang bekerja selama waktu yang sangat panjang dan morfologi tertakrifkan (Schroeder dalam Abduromansyah, dkk, 2015).

Air merupakan bahan yang sangat penting dalam proses reaksi pengikatan material-material yang digunakan untuk pembuatan batu bata. Untuk mendapatkan kualitas batu bata yang maksimal, maka air yang digunakan harus disesuaikan dengan standar yang ada (Raharjo, dkk, 2015).

Proses pembuatan batu bata melalui beberapa tahapan, meliputi penggalian bahan mentah, pengolahan bahan, pembentukan, pengeringan, pembakaran, pendinginan, dan pemilihan (seleksi).

Sifat fisis bata merah adalah sifat yang ada pada batu bata tanpa adanya pemberian beban atau perlakuan apapun. Sifat fisis batu bata (Andayono, 2017), antara lain yaitu warna bata berdasarkan bahan baku yang dibuat, biasanya berwarna coklat kemerahan (Amin, M, 2015). Kandungan kapur dan oksida besi pada bata merah memberikan warna merah setelah proses pembakaran.

Tabel .1 Ukuran dan Toleransi Bata Merah

\begin{tabular}{|c|c|c|c|}
\hline Mstel] & Tebalineni & Labar (nus) & Pzxjarzírmi \\
\hline $\mathrm{N}-)_{2}$ & $6 y=2$ & $y \| \pm 3$ & 9.42 \\
\hline N. 56 & $65-2$ & $201+$ & $59+2$ \\
\hline $\mathrm{N}-5 \mathrm{z}$ & $52=3$ & IIE & 23.44 \\
\hline $\mathrm{N}-\mathrm{S}_{\mathrm{n}}$ & $99=3$ & 1146 & $2 i t t^{5}$ \\
\hline X-kc & $T=3$ & 1146 & $23 \pm 5$ \\
\hline NLSA. & $S C=3$ & $1 \mathrm{~W}$ & 7345 \\
\hline
\end{tabular}

Sumber: SNI 15-2094-2000 dalam Andayono, 2017 
Bentuk batu bata berupa balok dengan ukuran panjang, lebar, tebal yang telah ditetapkan. Permukaan batu bata relatif datar dan kesat (Andayono, 2017).

Sifat mekanis bata merah adalah sifat yang ada pada batu bata jika dibebani atau dipengaruhi dengan perlakuan tertentu (Civil Engeneering Materials dalam Andayono, 2017). Sifat teknis batu bata, antara lain kuat tekan dan absorpsi.

\section{Kuat tekan bata merah}

Kuat tekan bata merah didapat sebagai hasil bagi beban tekan tertinggi dan luas bidang tekan terkecil (SNI 15-2094-2000). Kuat tekan bata merah dapat dihitung dengan Rumus 2.1 (SNI 15-2094-2000):

$$
\sigma=\frac{\mu}{A}
$$

Keterangan:

$\sigma=$ kuat tekan bata merah $\left(\mathrm{N} / \mathrm{mm}^{2}\right)$

$\mathrm{P}=$ beban maksimum $(\mathrm{N})$

$\mathrm{A}=$ luas penampang benda uji $\left(\mathrm{mm}^{2}\right)$

\section{Absorpsi bata merah}

Penyerapan adalah kemampuan maksimum batu bata untuk menyimpan atau menyerap air atau lebih dikenal dengan batu bata yang jenuh air. Pada penerapannya air adukan akan terserap oleh batu bata, air adukan ini berfungsi dalam proses pengerasan semen berkurang dan kekuatan mortar akan turun. Standar penyerapan batu bata yang disyaratkan oleh ASTM C 67-03 adalah masing-masing maksimum $13 \%$ dan $17 \%$. Menurut SNI Penyerapan air maksimum dari batu bata merah pejal untuk pasangan dinding yang diizinkan adalah maksimum sebesar $20 \%$.

\section{METODE PENELITIAN}

\section{Lokasi dan waktu penelitian}

Pembuatan bata merah pada penelitian ini dilakukan di pabrik bata milik Bapak Mansyur di jalan Pariwisata RT 2, Kelurahan Padang Nangka, Kecamatan
Singaran Patih, Kota Bengkulu. Pengujian kuat tekan bata merah dilakukan di Laboratorium Konstruksi dan Teknologi Beton Program Studi Teknik Sipil Fakultas Teknik Universitas Bengkulu. Waktu penelitian berlangsung lebih kurang 3 bulan.

\section{Metode Penelitian}

Metode yang digunakan dalam penelitian ini adalah metode eksperimen. Variasi durasi penginjakan adonan tanah liat, yang digunakan adalah 20, 25, 30, 32, 35 dan 40 menit.

Jumlah benda uji yang dibuat pada penelitian ini adalah 15 benda uji untuk bata normal dan 90 benda uji untuk bata variasi. Pengujian terhadap benda uji dalam penelitian ini dibagi menjadi dua jenis yaitu:

Tabel 2. Jumlah Benda Uji

\begin{tabular}{|c|c|c|c|c|c|c|c|}
\hline Penguin & \multicolumn{6}{|c|}{ 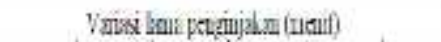 } & \multirow{2}{*}{ 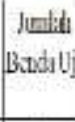 } \\
\hline 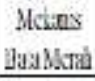 & 20 & 25 & 30 & 32 & 35 & to & \\
\hline Karat Iisen & 10 & 16 & 10 & 10 & 10 & II) & 60 \\
\hline Shoorps & 5 & 5 & 5 & 5 & 5 & 5 & 30 \\
\hline \multicolumn{7}{|c|}{ tath } & 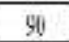 \\
\hline
\end{tabular}

Keterangan: 32 menit (waktu normal pemijakan adukan bata)

\section{Pengujian material pembentuk bata merah}

Pengujian sifat fisis tanah pada penelitian ini meliputi pengujian terhadap tanah liat dan pengujian terhadap adukan setiap variasi. Pengujian sifat fisis terhadap tanah liat yaitu:

1. Pengujian berat isi tanah mengacu pada SNI 03-3637-1994.

2. Pengujian berat jenis tanah mengacu pada SNI 1964-2008.

3. Pengujian kadar air tanah mengacu pada SNI 1965-2008.

4. Pengujian analisa saringan tanah mengacu pada SNI 3423-2008.

5. Pengujian batas plastis tanah mengacu pada SNI 1966-2008. 


\section{Pengujian bata merah}

Sifat fisis bata adalah sifat yang ada pada bata merah tanpa adanya pemberian beban atau perlakuan apapun. Pengujian fisis bata merah yaitu:

1. Pemeriksaan warna bata

Pemeriksaan warna bata dilakukan dengan mengamati warna bata setelah bata melalui proses pembakaran.

2. Pengukuran dimensi bata

Pengukuran dimensi bata dilakukan dengan cara mencatat ukuran panjang, lebar dan tinggi bata kemudian dirata- ratakan. Pengukuran dilakukansaat setelah pencetakan, setelah pengeringan dan setelah pembakaran.

3. Pemeriksaan tekstur bata

Pemeriksaan tekstur bata meliputi pemeriksaan bentuk secara visual dan kekesatan bata. Pemeriksaan ini dilakukan setelah pembakaran bata.

\section{Pengujian kuat tekan bata merah}

Pengujian kuat tekan bertujuan mengetahui nilai kuat tekan bata dengan menggunakan alat Compression Machine Hand Operated. Langkah-langkah pengujian kuat tekan menurut SNI 15-2094-2000 yaitu:

1. Bata merah diukur dimensinya untuk dipotong menjadi dua bagian.

2. Bata merah direndam untuk memudahkan perekatan mortar saat dicapping, adukan mortar disiapkan dengan perbandingan 1:3.

3. Potongan bata ditempatkan dalam alat cetakan capping dengan tebal $6 \mathrm{~mm}$.

4. Bata dicapping setebal $6 \mathrm{~mm}$ menggunakan adukan mortar.

5. Bata yang telah dicapping dilepaskan dari alat cetakan capping dan direndam dalam air bersih (suhu ruangan) selama 24 jam.

6. Bata diangkat dari bak perendaman kemudian diseka dengan kain lembab untuk menghilangkan air yang berlebihan.

7. Bata diuji tekan menggunakan alat compression machine hand operated dengan kapasitas $250 \mathrm{kN}$ hingga hancur.

8. Nilai kuat tekan bata adalah perbandingan nilai beban tekan maksimum dan luas bidang tekan.

\section{Pengujian absorpsi bata}

Alat yang digunakan dalam pengujian absorpsi bata yaitu :

1. Timbangan digital

2. Oven dengan suhu $110^{\circ} \mathrm{C}$.

Tahap pengerjaan absorpsi bata merah:

1. Penimbangan sampel bata untuk mengetahui berat awal bata.

2. Rendam sampel bata dalam air sampai tidak ada lagi rongga udara atau gelembung udara yang muncul.

3. Angkat bata dari bak perendaman kemudian bidang-bidangnya diseka dengan kain lembab untuk menghilangkan air yang berlebihan kemudian di timbang kembali beratnya.

4. Sampel bata dimasukkan ke dalam oven selama 24 jam dengan suhu $110^{\circ} \mathrm{C}$.

5. Mengeluarkan sampel bata dari oven dan di dinginkan bata sekitar 10 menit.

6. Timbang berat bata yang telah di dinginkan.

7. Hitung absorpsi sampel bata dengan menggunakan rumus di bawah ini

$$
\mathrm{P}=\frac{w s-w c}{w d}
$$

\section{HASIL DAN PEMBAHASAN}

\section{Kuat tekan bata merah}

Bata merah yang diuji kuat tekan terlebih dahulu dicapping supaya permukaan bata merah rata. Hasil uji kuat tekan bata merah dapat dilihat pada Grafik kuat tekan bata merah dapat dilihat pada Gambar 1. 


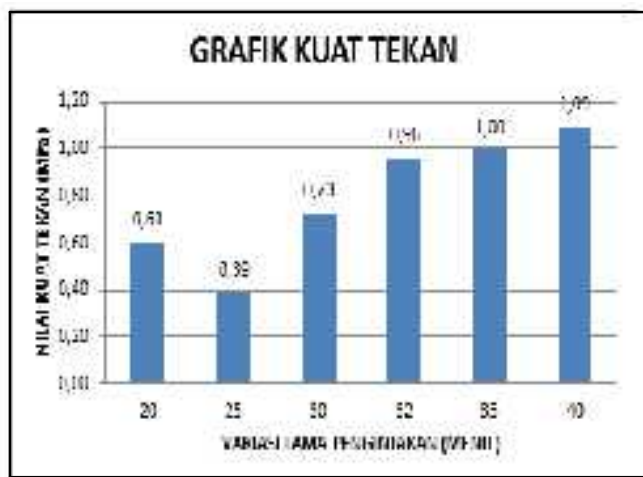

Gambar 1. Grafik Hubungan Kuat Tekan Bata Merah dengan Lama Penginjakan Adukan

Grafik pada Gambar 1 menunjukkan bahwa lama penginjakan adukan bata menghasilkan kuat tekan bata merah variasi lebih tinggi. Nilai kuat tekan terbesar terjadi pada variasi 40 menit dengan nilai kuat tekan rata-rata sebesar 1,09 MPa. Hal ini dikarenakan pada varisi ini proses peminjakan adonan bata yang lama dan berpengaruh pada padatnya adonan bata. Kuat tekan terendah terjadi pada variasi 25 menit, terjadi karena pada saat pengujian benda uji varisi ini kadar air adukan lebih besar dan berat isi adukan yang kecil.

\section{Absorpsi bata}

Pemeriksaan absorpsi bata (Tabel 3) nilai rata-rata absorpi bata terendah yaitu pada sampel dengan waktu penginjakan 40 menit sebesar $5,41 \%$ dan nilai rata-rata yang tertinggi yaitu pada sampel dengan waktu penginjakan selama 20 menit yaitu sebesar 9,82\%. Semakin lama proses penginjakan adukan tanah liat membuat persentasi absorpsi pada bata merah semakin kecil.

Tabel 3. Nilai Absorpsi

\begin{tabular}{|c|c|}
\hline Lama Penginjakan (menit) & Absorpsi (\%) \\
\hline 20 & 9 \\
\hline 25 & 7 \\
\hline 30 & 5 \\
\hline 32 & 6 \\
\hline 35 & 5 \\
\hline 40 & 5 \\
\hline
\end{tabular}

Jurnal Inersia Oktober2018 Vol.10 No.2

Email:Inersia@unib.ac.id

\section{KESIMPULAN}

1. Nilai kuat tekan tertinggi bata variasi adukan yang lama penginjakannya selama 40 menit yaitu sebesar 1,09 MPa.

2. Persentase variasi lama penginjakan adukan berpengaruh membuat kekuatan bata meningkat, semakain lama waktu yang digunakan pada proses penginjakan semakin besar kuat tekan bata.

3. Kuat tekan terendah terjadi pada bata variasi adukan dengan waktu penginjakan 25 menit yaitu sebesar 0,36 MPa disebabkan oleh kadar air adukan lebih besar dan berat isi adukan.

4. Semakin lama proses penginjakan adukan didapatkan bata yang semakin rendah absorpsinya.

5. Warna bata setelah proses pembakaran tidak mengalami perbedaan dari beberapa varisi penginjakan yaitu orange kecoklatan, permukaan bata yang relatif datar, halus, dan rata- rata siku.

\section{DAFTAR PUSTAKA}

Abdurrohmansyah., Adha, I., Ali, H., 2015, Studi Kuat Tekan Batu Bata menggunakan Bahan Additive (Abu Sekam Padi, Abu Ampas Tebu dan Fly Ash) Berdasarkan Spesifikasi Standar Nasional Indonesia (SNI), JRSDD Vol.3, No.3, Jurusan Teknik Sipil, Fakultas Teknik, Universitas Lampung.

Amin M., 2015, Inovasi Material pada Pembuatan Bata Merah Tanpa Dibakar untuk Kemakmuran Industri Kerakyatan, UPT Balai Pengolahan Mineral Lampung-LIPI, J1. Ir. Sutami KM.15 Tanjung Bintang Lampung Selatan.

Andayono T., 2017, Kualitas Batu Bata Pasca Sosialisasi Persyaratan Pokok Membangun Rumah Lebih Aman Gempa, Jurusan Teknik Sipil, Fakultas Teknik Universitas Negeri Padang. 
Handayani S., 2010. Kualitas Batu Bata Merah dengan Penambahan Serbuk Gergaji, Jurnal Teknik Sipil Vol. 12, Jurusan Teknik Sipil, Fakultas Teknik, Universitas Negeri Semarang, Semarang.

Raharjo, M.T., Sumarni, S., Rahmawati, A., 2015, Pengaruh Penggunaan Abu Vulkanik sebagai Pengganti Sebagian Tanah Liat pada Batu Bata terhadap Kuat Tekan, Berat Jenis dan Daya Resapan Air sebagai Pendalaman
Materi Konstruksi Bangunan di SMK Teknik Bangunan, Jurusan Pendidikan Teknik Kejuruan, Universitas Sebelas Maret.

Rahman, H., Wisnumurti, Zacoeb, A., 2016, Uji Kuat Tekan Bata Merah Menggunakan Mortar Pasir Kwarsa, Jurusan Teknik Sipil, Fakultas Teknik, Universitas Brawijaya Malang, Jalan MT. Haryono 167 Malang 65145, Jawa Timur 